\title{
INCIDENTE DE DESLOCAMENTO DE COMPETÊNCIA - DA DOGMÁTICA À JURISPRUDÊNCIA DO SUPERIOR TRIBUNAL DE JUSTIÇA: O PROCESSO A SERVIÇO DOS DIREITOS HUMANOS
}

\section{ARTIGO ORIGINAL}

BARBOSA, André Luciano ${ }^{1}$, MATSUSHITA, Thiago Lopes²

BARBOSA, André Luciano. MATSUSHITA, Thiago Lopes. Incidente de deslocamento de competência - da dogmática à jurisprudência do superior tribunal de justiça: o processo a serviço dos Direitos Humanos. Revista Científica Multidisciplinar Núcleo do Conhecimento. Ano 06, Ed. 05, Vol. 05, pp. 1835. Agosto de 2021. ISSN: 2448-0959, Link de acesso: https://www.nucleodoconhecimento.com.br/lei/jurisprudencia, DOI: 10.32749/nucleodoconhecimento.com.br/lei/jurisprudencia

\section{RESUMO}

Já se passaram mais de 15 anos da introdução normativa do Incidente de Deslocamento de Competência (IDC) no ordenamento jurídico brasileiro, por meio da aprovação da Proposta de Emenda Constitucional (PEC) ㄲo 45/04. Neste artigo será apresentado o que se verificou neste interregno temporal com o Instituto em apreço, bem como responder o que pode ser aperfeiçoado no aspecto processual e humanitário, para fins de ampliação dos seus efeitos. O tempo de vigência do Instituto permite, agora, com a clareza necessária, visualizar os impactos positivos e negativos do IDC na realidade prática do Poder Judiciário brasileiro. Este artigo tem o escopo de trabalhar o IDC de forma ampla, isto é, desde as suas bases constitucionais e convencionais, passando pela balizada doutrina nacional, que melhor cuida da temática, e, em seguida, pela jurisprudência atualizada do Superior

\footnotetext{
${ }^{1}$ Mestrando em Direito pela PUC-SP, Especialista em Direito Administrativo pela PUC-SP, Especialista em Direito Privado pela Escola Paulista da Magistratura, Bacharel em Direito pela PUC-SP.

${ }^{2}$ Doutorado em Direito. Orientador.
} 
Tribunal de Justiça (STJ). A metodologia fundamental utilizada nas construções e reflexões deste artigo é a bibliográfica e explicativa, com ampla pesquisa em livros da área jurídica especializada, sem abandonar os métodos indutivos e dedutivos, a partir da jurisprudência de casos concretos que serão analisados. Com objetividade e análise crítica, o leitor, ao final, irá assimilar o que há de mais importante e atualizado sobre o IDC no Brasil, sem prejuízo de propostas inovadoras. Nesse sentido, chega-se a importantes conclusões, como a necessidade de ampliação dos legitimados para sua propositura, assim como a ampliação de sua aplicação para os casos cíveis e, também, a fixação de melhores balizas para as conclusões das investigações criminais e cíveis.

Palavras-chave: Incidente de Deslocamento de Competência, Direitos Humanos, Lei, Doutrina, Jurisprudência.

\section{INTRODUÇÃO}

A Emenda Constitucional (EC) no 45, publicada no dia 31 de dezembro de 2004, popularmente rotulada pelos veículos de imprensa como a emenda da "reforma do Poder Judiciário", inaugurou no ordenamento jurídico o denominado Incidente de Deslocamento de Competência (IDC), nesta esteira, incluiu o §5ำ e o inciso V-A ao Art. 109 da CF/88. Importante registrar que a federalização das violações de Direitos Humanos já era prevista como meta do Programa Nacional de Direitos Humanos desde 1996. (BRASIL, 1988)

Desde logo, aponta-se que há ações diretas de inconstitucionalidade pendentes de julgamento objetivando a declaração de inconstitucionalidade do incidente de deslocamento de competência (ADI 3493/DF e ADI 3486/DF), ambas ajuizadas em 2005 e conclusas ao Relator Dias Toffoli, desde março de 2017, com data de julgamento prevista para o dia 06/08/21. Os principais argumentos destas ações são a violação do princípio do juiz natural, a quebra do pacto federativo e a violação ao devido processo legal. As demandas têm remota possibilidade de êxito, inclusive, porque o STJ, no primeiro IDC (IDC no 1 - Dorothy Stang), expressamente afirmou 
que: "Aparente incompatibilidade do IDC, criado pela EC n 45/04, com qualquer outro princípio constitucional ou com a sistemática processual em vigor de ser resolvida aplicando-se os princípios da proporcionalidade e da razoabilidade". Percebe-se, portanto, que a Corte Superior, ainda que seja o STJ, entendeu pela constitucionalidade do incidente (STJ, 2005).

Neste estudo, busca-se explorar o que se verificou com o IDC desde sua implementação no ordenamento jurídico brasileiro, respondendo objetivamente o que pode ser aperfeiçoado no seu aspecto processual e humanitário, para fins de ampliação dos seus efeitos práticos.

Cediço que, nestes mais de 15 anos de vigência do IDC, hoje é possível, com a maturidade necessária, fazer reflexões sobre este relevante instrumento processual a serviço dos Direitos Humanos, à luz de suas bases constitucionais, convencionais e do que a jurisprudência do STJ produziu sobre o tema, trazendo também ponderações críticas e evolutivas.

\section{FUNDAMENTOS CONSTITUCIONAL, CONVENCIONAL E COMPETÊNCIA PARA JULGAMENTO DO INCIDENTE DE DESLOCAMENTO DE COMPETÊNCIA (IDC)}

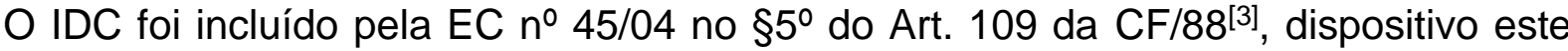
que lhe serve de berço constitucional. O incidente é conhecido e julgado no âmbito do Superior Tribunal de Justiça (Art. 109, §5으, da CF/88) e, uma vez julgada procedente a demanda que ensejou o incidente, esta deve ser deslocada para a Primeira Instância da Justiça Federal (Art. 109, V-A, CF/88 ${ }^{[4]}$ ). Dispõe o Art. 1ํㅡ, parágrafo único, da Resolução nำ6, de 16/05/2005 do STJ, que a competência para julgar o incidente é da Terceira Seção do STJ, que é composta por Ministros da 5a e 6 - turmas da Corte. O único legitimado para tal propositura é o Procurador Geral de Justiça, trata-se, portanto, de uma legitimação exclusiva. Ressalte-se, ainda, que o incidente pode ser levado a efeito tanto na fase de inquérito e quando durante o processo, de causas cíveis ou penais. (BRASIL, 1988; BRASIL, 2005) 
O fundamento convencional está no Art. 28 da Convenção Americana de Direitos Humanos (CADH) ${ }^{[5]}$, a qual foi incorporada pelo Brasil pelo Decreto ํㅡ 678, de 6 de novembro de 1992. O artigo traz em seu bojo a denominada cláusula federal. A União compõe juntamente com o Estados, Município e o Distrito Federal a República Federativa do Brasil. A União é pessoa jurídica de direito público interno, mas também representa a República Federativa do Brasil no âmbito externo. A União representa o Estado Federal Brasileiro nos atos de Direito Internacional, uma vez que estes atos são de responsabilidade do Presidente da República (Art. 21, I, $\mathrm{CF} / 88$ ). As responsabilidades pactuadas em âmbito internacional, como aquelas assumidas na $\mathrm{CADH}$ são, em última análise de responsabilidade da República Federativa do Brasil, representadas pela União exercida pelo seu presidente. (BRASIL, 1988)

Desta feita, por mais que haja divisões internas de competência nos Estados Federados (competência horizontal, vertical, material, legislativa etc.), perante os Órgãos internacionais a responsabilidade é da União. Nesse cenário, a cláusula federal aponta que as responsabilidades assumidas nos tratados serão exigidas da União (República Federativa do Brasil) e não dos demais Entes componentes do Estado Federado, ainda que seja deles a competência para atuação de salvaguarda do direito previsto no tratado, haja vista que estes não têm personalidade de direito público internacional.

Piovesan (2013, p. 395), em seu livro "Direitos Humanos e o Direito Constitucional Internacional", discorre sobre a responsabilidade da União, in verbis:

De acordo com o Direito Internacional, a responsabilidade pelas violações de Direitos Humanos é sempre da União, que dispõe de personalidade jurídica internacional. Nesse sentido, os princípios federativo e da separação dos Poderes não podem ser invocados para afastar a responsabilidade da União em relação à violação de obrigações contraídas no âmbito internacional.

Há uma ponderação relevante aqui baseada na competência. A maioria dos casos de violação aos Direitos Humanos ocorrem em âmbito do Estado Federal, uma vez que a competência da Justiça Estadual é muito mais ampla, mas, paradoxalmente, é 
a União que é responsável internacionalmente. Portanto, há um paradoxo entre aquele que mais descumpre (Estados) e aquele que é responsabilizado juridicamente (Federal).

Neste ponto, a dogmática da matéria não dá margem para maiores interpretações jurídicas. Tem se o fundamento constitucional (Art. 109, V-A e §5ํ, da CF/88), convencional (Art. 28 da CADH), a competência do STJ, e, julgado procedente, o deslocamento do processo ou investigação para a Justiça Federal de Primeira Instância.

\section{LEGITIMIDADE PARA A PROPOSITURA DO INCIDENTE DE DESLOCAMENTO DE COMPETÊNCIA}

A Constituição Federal expressamente aponta como legitimado exclusivo para a propositura do incidente de deslocamento de competência o Procurador Geral da República. Há aqui ponderações relevantes que merecem discussão profunda, haja vista que esta legitimidade exclusiva é causa e efeito de inúmeras consequências práticas. Não se desconhece que o Procurador Geral da República é o chefe do Ministério Público da União, que é composto pelo Ministério Público Federal, do Trabalho, Militar e do Distrito Federal e Territórios (Art. 128, I e $\$ 1^{\circ}$, CF/88), motivo pelo qual representa os interesses políticos-jurídicos desta classe. Ocorre que, limitar a possibilidade de o incidente ser exclusivamente ajuizado pelo Procurador Geral é atentar contra a premissa básica de pluralidade de legitimidade adotada pela Constituição Federal, inclusive, em demandas processuais de grande envergadura como ADI (Ação Direta de Inconstitucionalidade), ADC (Ação Declaratória de Constitucionalidade), ADO (Ação Direta de Inconstitucionalidade por Omissão) e ADPF (Arguição de Descumprimento de Preceito Fundamental) ${ }^{[6]}$ (BRASIL, 1988). Não por outra razão, dispõe o Art. 129, $§ 1^{\circ}$, da CF/88 que a legitimação do Ministério Público para as ações civis previstas no Art. 129 não impede a de terceiros, nas mesmas hipóteses, segundo o disposto na Constituição e na lei. 
É importante ressaltar que tutelar os Direitos Humanos é tarefa de todos os Poderes constituídos da República e não apenas do Ministério Público da União (MPU). O Chefe do MPU, não raras vezes, segue envolvido em constantes questões políticas que fazem com que não despenda a energia necessária para tão importante tarefa.

A Defensoria Pública (DPU), que representa os interesses da população vulnerável e a Advocacia Geral da União (AGU), que representa os interesses do Governo Federal, deveriam, evidentemente, constar do referido rol. A presença da legitimidade da Defensoria decorre da circunstância de ser a única encarregada expressamente pelo poder constituinte derivado (EC № 80/14) da promoção dos Direitos Humanos (Art. 134, caput, da CF/88) ${ }^{[7]}$. A principal Instituição da República encarregada por tutelar vulneráveis, promovendo os Direitos Humanos, não está autorizada a promover o IDC. Não há o menor sentido jurídico, ético ou moral para tanto. Não por outro motivo, a PEC 31/17 ${ }^{[8]}$ (BRASIL, 2017) visa corrigir tamanho equívoco concedendo legitimidade ao Defensor Público Geral Federal a possibilidade de manejo do IDC.

Obviamente, por simetria, Órgãos Estaduais devem ser alçados à condição de legitimados para a propositura do incidente. O motivo é muito singelo. Não apenas casos de repercussão nacional e escolhidos pela mídia de massa devem ser respondidos com precisão cartesiana pelo Poder Judiciário, mas também, e não menos importantes, os de repercussão regional ou local. Neste contexto, defende-se que ao menos os Defensores Públicos Gerais dos Estados, mais o do Distrito Federal, os Procuradores Gerais de Justiça, que representam os interesses dos Ministérios Públicos Estaduais e os Chefes das Procuradorias Gerais dos Estados, devem estar no rol de legitimados.

Há diversas violações de Direitos Humanos em âmbito regional e local que acabam sendo relegadas pelas autoridades Estaduais, o que não se pode coadunar, os direitos das mulheres, idosos, crianças, indígenas, dentre outros, são comumente desrespeitados pelas autoridades regionais e locais. O aumento do número de legitimados autorizaria maior controle das graves violações aos Direitos Humanos 
ocorridas no Brasil, visto que, traria maior sindicância jurídica sobre essas violações. Ao invés de apenas um legitimado, se teria um corpo quantitativo maior e vigilante, acarretando um aumento quantitativo dos IDCs. Sob esta perspectiva, seria de suma importância que Órgãos que representem a sociedade civil também fossem legitimados para tal empreitada, como bom exemplo, seria a Ordem dos Advogados do Brasil Federal e Estaduais. O incidente tem importante função de controle dos Órgãos investigativos e jurisdicionais, por isso, o aumento significativo de legitimados causaria importante reflexo nos impasses verificados em âmbito regional e local.

Mazzuoli (2015, p. 232), em seu livro "Curso de Direitos Humanos", trata da dupla finalidade da federalização das graves violações de Direitos Humanos, in litteris:

a) uma preventiva, a induzir o Judiciário Estadual a zelar mais eficazmente pelo cumprimento dos Tratados de Direitos Humanos dos quais o Brasil é parte, tomando medidas destinadas a impedir a impunidade sob o risco de deslocamento da competência; e

b) uma repressiva, a demonstrar a eventual ineficácia das instâncias estaduais em lidar com questões graves de violação de direitos humanos. Por outro lado, a federalização redobra a responsabilidade da Justiça Federal para a persecução e combate efetivo da impunidade das referidas violações de Direitos H

Não se vê impasse objetivo de um relevante Órgão Estadual ou mesmo representante da sociedade civil, verificando flagrante atentado aos Direitos Humanos em âmbito regional e local, postular perante o STJ, recursos e demandas originárias (por exemplo, recurso especial, HCs, MSs etc.) são constantemente propostos perante o STJ por Órgãos Estaduais, sem que isso justifique, sobremaneira, qualquer impedimento de atuação derivada ou originária.

A Doutrina de Piovesan (2013, p. 399), em seu livro "Direitos Humanos e o Direito Constitucional Internacional", também revela sua insatisfação com a legitimidade limitada, oportuna à transcrição:

Ademais, a emenda poderia ter previsto outros legitimados para o incidente de deslocamento (como o próprio Conselho de Defesa dos Direitos da 
Pessoa Humana) e não ter optado por centrar tal legitimidade exclusivamente no Procurador-Geral da República. É de rigor que se democratize o acesso ao pedido de deslocamento e outros relevantes atores sociais.

Ressaltando que o único legitimado expresso no texto constitucional é o Procurador Geral da República que, até hoje manejou por volta de 12 incidentes, passa-se agora à análise dos aspectos da competência material.

\section{COMPETÊNCIA MATERIAL DO IDC: QUAIS SÃO OS TRATADOS DE DIREITOS HUMANOS QUE O BRASIL ADERIU?}

A competência material informa a base de direito material que autoriza a propositura do IDC. Em outras palavras, quais direitos violados autorizariam o manejo do IDC perante o STJ.

A jurisdição é tradicionalmente conceituada como o dever-poder de dizer o direito em determinado território. Assim, um juiz do Estado de São Paulo tem jurisdição em todo o Brasil, mas, evidentemente, não a tem para julgar todos os casos do Brasil ou mesmo de São Paulo, o que faz surgir o conceito de competência. A competência, por sua vez, é o limite, a medida da jurisdição no caso concreto. O IDC tem por finalidade federalizar atos graves contra os Direitos Humanos, notem, não se trata apenas de crimes, há possibilidade de deslocamentos também no âmbito civil, assegurando a proteção dos Direitos Humanos previstos nos tratados internacionais, os quais o Brasil é signatário e, consequentemente, se comprometeu em resguardar, tutelar, proteger e assegurar (PIOVESAN, 2013).

O IDC flexibiliza expressamente o princípio do juiz natural consagrado no Art. 5ํㅡ, LIII, da CF/88 ${ }^{[9]}$. Frise-se que diversos institutos processuais vigentes no Brasil, como a conexão (Art. 55 do CPC), continência (Art. 56 do CPC), desaforamento (Art. 427 do CPP), prerrogativa de função (súmula 704 do STF), dentre outros, também militam nesse sentido, com o escopo de equalizar os impasses processuais, dando maior racionalidade ao sistema jurídico. Aponta-se, apenas, que o IDC não traz em seu bojo essencialmente a racionalidade do sistema processual (economia e 
instrumentalidade processuais, evitar a produção de decisões contraditórias etc.), mas sim a ideia de justiça do sistema, visto que objetiva alcançar uma resposta jurisdicional efetiva àquele que sofreu grave violação de algum direito humano fundamental.

O dispositivo constitucional expressamente consagra que o IDC pode ser instaurado para tutelar Tratados de Direitos Humanos dos quais o Brasil faz parte. Portanto, deve-se responder: quais Tratados de Direitos Humanos o Brasil é signatário? Abaixo segue o rol de declarações e tratados, acrescidos daqueles que o Brasil ratificou com status de EC (Art. 5ª, $3^{\circ}$, da CF/88), in verbis:

\section{I- Declarações de Direitos Humanos aprovadas pelo Brasil:}

a) Sistema Global: Declaração Universal dos Direitos Humanos - 1948; Declaração do Direito ao Desenvolvimento - 1986; Declaração e Programa de Ação de Viena 1993; e Declaração de Pequim - 1995.

b) Sistema Regional Interamericano: Declaração Americana dos Direitos e Deveres do Homem - 1948.

II- Tratados Internacionais de Proteção de Direitos Humanos ratificados pelo Brasil:

a) Sistema Global: Preceitos da Carta das Nações Unidas - 1945; Convenção contra

o Genocídio - 1949; Convenção relativa ao Estatuto dos Refugiados - 1951; Protocolo sobre o Estatuto dos Refugiados - 1966; Pacto Internacional dos Direitos Civis e Políticos - 1966; Pacto Internacional dos Direitos Econômicos, Sociais e Culturais - 1966; Convenção sobre a Eliminação de todas as formas de Discriminação Racial - 1968; Convenção sobre a Eliminação de todas as formas de Discriminação contra a Mulher - 1984; Convenção contra a Tortura e outros Tratamentos ou Penas Cruéis, Desumanos ou Degradantes 1984; e Convenção sobre os Direitos da Criança - 1989 
b) Sistema Regional Interamericano: Convenção Americana sobre Direitos Humanos - 1969; Convenção Interamericana para Prevenir e Punir a Tortura - 1985; e Convenção Interamericana para Prevenir, Punir e Erradicar a Violência contra a Mulher - 1994

III - Tratados incorporados pelo Brasil com status de emenda constitucional (Art. 50, §3, CF/88):

Convenção Internacional sobre os Direitos das Pessoas com Deficiência e seu Protocolo Facultativo - 2007; e Tratado de Marraqueche para Facilitar o Acesso a Obras Publicadas às Pessoas Cegas, com Deficiência Visual ou com Outras Dificuldades para Ter Acesso ao Texto Impresso - 2013

A simples listagem dos Tratados Internacionais de Direitos Humanos aos quais o Brasil aderiu leva à forçosa conclusão de que é impossível o Procurador Geral da República, único legitimado constitucional, realizar efetiva tutela e controle do que ocorre em todo o País, da fase investigativa à satisfativa, no que tange a esses Direitos Materiais. Conforme já dito, o alargamento do rol de legitimados traria maior possibilidade de que os Direitos Humanos lesados fossem, de fato, resguardados, tutelados, protegidos e assegurados pelo sistema Federal de Justiça.

A quantidade de direitos materiais assegurados pelos Tratados Internacionais de Direitos Humanos dos quais o Brasil se comprometeu (direito: da Mulher, da Criança, do Preso etc.) estão muito distantes de serem concretamente protegidos pelo sistema legal brasileiro. É importante frisar, mais uma vez, que os tratados cuidam de diversos temas, não apenas de ordem criminal, que precisam de real tutela das Instituições Brasileiras constituídas.

As lições de Ramos (2014, p. 73), em seu livro "Teoria Geral dos Direitos Humanos na Ordem Internacional": "O Direito Internacional dos Direitos Humanos consiste no conjunto de direitos e faculdades que garante a dignidade do ser humano e se beneficia de garantias internacionais institucionalizadas". Em suma, os tratados internacionais trazem em seu bojo princípios e normas que regulamentam a 
cooperação internacional com o escopo de promover os Direitos Humanos e as liberdades básicas internacionalmente reconhecidas.

\section{EMBATE ENTRE A JUSTIÇA FEDERAL E JUSTIÇA ESTADUAL}

Não se pode deixar de tecer algumas considerações, ainda que breves, neste artigo, que tem por escopo principal cuidar dos meandros do IDC em sua completude, da polêmica verificada entre as Justiças Federal e Estadual, durante e após a provação do IDC.

As ADls (3493 e 3486) ajuizadas respectivamente pela ANAMAGES (Associação Nacional dos Magistrados Estaduais) e Associação dos Magistrados Brasileiros $A M B$, sendo que nesta última em conjunto também com a ANAMAGES, em certa medida, relevam este desconforto entre as Justiças levado a efeito pela constitucionalização do incidente. Há uma "batalha de egos" histórica entre as Justiças Federal e Estadual no Brasil, não apenas no que tange à competência processual e material, mas também vencimentos, orçamentos, estrutura etc. Seria, então, a Justiça Estadual incapaz, em certas circunstâncias, de dar uma efetiva resposta aos Direitos Humanos lesados? Motivo pelo qual o IDC se justificaria? Ao que parece, em mais de uma situação, isso de fato ocorreu.

Logo que foi promulgada a EC no $15 / 04$ muito se debateu sobre a pouca efetividade da Justiça Estadual para solucionar grandes embates de Direitos Humanos travados nas mais distantes Comarcas do Brasil. Este estudo não tem por objetivo debater questões políticas ou institucionais existentes entre estas duas Justiças do Brasil. Há uma rivalidade histórica entre as Justiças Estadual e Federal relacionada a vencimentos, competência, autonomia financeira, administrativa etc. Incontroverso, na dinâmica dos fatos, é que a competência da Justiça Estadual é muito mais ampla do que a da Justiça Federal, aliado a isso, incontestável que as Comarcas menores sofrem forte influência das lideranças locais, sejam elas políticas, sociais ou econômicas, o que muitas vezes impede a regular investigação, julgamento e satisfação do título executivo conquistado. Ao final, o que se vê é uma verdadeira 
situação de injustiça. O IDC foi criado justamente para tentar minimizar esta disfuncionalidade histórica, para reduzir injustiças flagrantes, motivos estes que se sobrepõem aos interesses funcionais, morais, pessoais, organizacionais, de determinada classe corporativa.

Sob o enfoque pragmático, a Doutrina de Piovesan (2013 p. 397), no seu Direitos Humanos e o Direito Constitucional Internacional, enfrente o tema:

\begin{abstract}
Por meio da federalização das violações de direitos humanos, cria-se um sistema de salutar concorrência institucional para o combate à impunidade. De um lado, a federalização encoraja a firme atuação do Estado, sob o risco do deslocamento de competências. Isto é, se as instituições locais se mostrarem falhas, ineficazes ou omissas para a proteção dos direitos humanos, será possível valer-se das instâncias federais. Por outro lado, a federalização aumenta a responsabilidade das instâncias federais para 0 efetivo combate à impunidade das graves violações aos direitos humanos. $\mathrm{O}$ impacto há de ser o fortalecimento das instituições locais e federais. [...] A responsabilidade primária no tocante aos direitos humanos é dos Estados, enquanto a responsabilidade subsidiária passa a ser da União.
\end{abstract}

A visão não é tão otimista, ainda mais da forma como foi desenhado o instituto e de sua prática mais de 15 anos depois da vigência, de qualquer forma, fica o registro da melhor Doutrina e a esperança conjunta e renovada de dias melhores.

Enfrentado o assunto, passa-se agora para o estudo das questões processuais relevantes.

\title{
6. QUESTÕES PROCESSUAIS DO IDC
}

Neste ponto, serão tratados detalhes processuais do IDC que são dignos de nota. As reflexões abaixo são frutos das decisões do STJ. Esta pesquisa através de os IDCs ajuizados no STJ encontrou pedidos de tutela antecipada (ou liminar) para o imediato deslocamento de competência (IDC nํ5/PE). O pedido de antecipação dos efeitos da tutela, em tese, é possível, preenchidos os requisitos legais para tanto, no IDC mencionado o pedido não foi acolhido. 
Conforme já apontado, a competência para julgar o incidente é da Terceira Seção do STJ, que é composta por Ministros da $5^{\underline{a}}$ e $6^{a}$ turmas da Corte (Art. 1ํㅜㄹ parágrafo único, da Resolução oำ 6, de 16/05/2005 do STJ). No total são dez ministros que participam da votação, sendo que o presidente apenas vota no caso de empate. Há possibilidade de sustentação oral, por quinze minutos, depois da relatoria se inicia a votação em ordem decrescente de antiguidade. Ademais, há possibilidade de vistas, o que suspende o julgamento, sendo o prazo para devolução de 60 dias, a contar da disponibilização dos autos, prorrogável por mais 30 dias, mediante requerimento formulado ao colegiado (BRASIL, 2005). Os prazos ficam suspensos nos períodos de férias ou recesso do Tribunal (Art. 162 e 163 do Regimento Interno do STJ).

Anote-se, também, que o STJ tem admitido a figura do "amicus curiae" (amigo da corte ou auxiliar da corte) no incidente, o que traduz maior democratização ao trâmite processual do instituto, conferindo a possibilidade de oitiva de pessoas físicas ou jurídicas que podem contribuir para melhor solução da controvérsia (IDC no 9, 24, dentre outros). Apenas uma curiosidade, no IDC no 24, que trata do caso Marielle Franco e Anderson Gomes, a relatora deferiu prazo para familiares e acusados se manifestarem sobre o pedido de incidente.

Registre-se, por fim, que o Procurador Geral da República não está vinculado à sua manifestação inicial no incidente. Desse modo, não obstante tenha proposto o IDC, como legitimado exclusivo, se durante o curso do incidente entender que é o caso de rever seu posicionamento, exarando parecer em sentido contrário, como ocorreu no IDC no 3, não haverá qualquer incongruência processual ou autofagia técnica. $A$ manifestação em parecer a favor ou a título de retratação por parte do PGR não vincula a decisão jurisdicional do Órgão competente, não havendo que se falar em de falta de interesse de agir superveniente à propositura, visto que a demanda, tem natureza objetiva.

O feito tem trâmite regular perante as turmas do STJ, tendo sido admitida a oposição de embargos de declaração (EDcl) (IDC № 5/PE - EDcl 2014/0101401-7) após o julgamento. Não se tem notícia da admissibilidade de outros recursos, ressalvando- 
se, apenas, a possibilidade de agravo regimental (AgRg) das decisões monocráticas do relator sorteado ou substituto (IDC n 5/PE - AgRg 2014/010140-7) e recuso extraordinário para o STF.

O Art. $2^{\circ}$ da Resolução 6, de 16/02/2005, do STJ expressamente registra que fica sobrestado o pagamento de custas nos processos de IDC, até que o tribunal delibere sobre o tema. Não se tem notícia de qualquer deliberação a respeito das custas, o que leva à forçosa conclusão de que não há recolhimento a este título, até porque a demanda é manejada pelo PGR que tem isenção de custas (Art. 4ํㅡㄴ, III, da Lei no 9.289/96). Também não há necessidade de procuração. O impasse das custas e da procuração assumiria outro vértice com o alargamento do rol de legitimados, o que não se verificou até o momento. (BRASIL, 1996)

Não há norma regulando especificamente o incidente em questão, motivo pelo qual é muito importante uma interpretação sistemática dos institutos processuais que podem alimentar o IDC.

Abaixo, agora, os incidentes em espécie, trabalhando os requisitos desenvolvidos pela jurisprudência do STJ.

\section{ANÁLISE DE CASOS DOS IDCS E REQUISITOS DE ADMISSIBILIDADE CONSAGRADOS PELA JURISPRUDÊNCIA}

Ramos (2014, p. 34), traz em seu livro "Teoria Geral dos Direitos Humanos na Ordem Internacional": "Na necessidade de se adotar uma definição concisa, entendo por direitos humanos um conjunto mínimo de direitos necessários para assegurar uma vida do ser humano baseada na liberdade, igualdade e na dignidade".

Antes de iniciar o estudo dos casos em particular, entende-se importante, analisar os principais argumentos da jurisprudência do STJ quanto ao julgamento dos IDCs, permitindo, assim, melhor compreensão sobre a matéria. 
Excepcionalidade, necessidade, imprescindibilidade, razoabilidade e proporcionalidade da medida, observada a exigência de se reunir os seguintes pressupostos para o seu deferimento: (1) a existência de grave violação a direitos humanos; (2) o risco de responsabilização internacional decorrente do descumprimento de obrigações jurídicas assumidas em tratados internacionais; e (3) a incapacidade das instâncias e autoridades locais de oferecer respostas efetivas. Todos os requisitos devem estar presentes cumulativamente. Pode ser antes do processo (IDC no 5), como na fase de exceção, isto é, é possível após o trânsito em julgado (IDC no 10) ou mesmo na fase recursal, podendo retirar a competência da justiça especial, por exemplo, da justiça militar para a justiça federal comum (IDC no 14).

Outro argumento recorrente nos incidentes indeferidos é a possibilidade de colaboração na instrução processual entre os Entes Federados e a União, ou seja, a possibilidade de a Justiça Estadual solicitar auxílio técnico e/ou operacional, se necessário, da Polícia Federal, atendendo, em certa medida, ao disposto no Art. 3ํㅡㄴ VIII, da Lei no 12.850/2013. Este último argumento objetiva perfectibilizar um verdadeiro cooperativismo democrático finalista, muito interessante e certamente exitoso, mas que, na prática, é de difícil concretização, não só diante dos entraves burocráticos, mas também haja vista a resistência moral (corporativa) entre os envolvidos nesta "ajuda" mútua.

A jurisprudência também aprofunda em distinções interessantes sobre os requisitos, para tanto, a incapacidade ou ineficácia difere da ineficiência. A incapacidade ou ineficácia estariam relacionados com a integral omissão (oriunda de inércia, omissão, negligência, falta de vontade política, de condições pessoais e/ou materiais etc. - rol exemplificativo previsto no item 2 do IDC 5/PE) em relação às atividades legais de responsabilização, enquanto, a ineficiência se traduz na ausência de resultados investigativos capazes de ensejar consequências no âmbito jurídico. Nesse sentido, oportuna a transcrição dos itens 6 e 7 do IDC 3/GO: 
6. Não se pode confundir incapacidade ou ineficácia das instâncias e autoridades locais com ineficiência. Enquanto a incapacidade ou ineficácia derivam de completa ignorância no exercício das atividades estatais tendentes à responsabilização dos autores dos delitos apontados, a ineficiência constitui a ausência de obtenção de resultados úteis e capazes de gerar consequências jurídicas, não obstante o conjunto de providências adotadas. 7. Ainda que seja evidente que a ineficiência dos órgãos encarregados de investigação, persecução e julgamento de crimes contra os direitos humanos, é situação grave e deve desencadear no seio dos Conselhos Nacionais e dos órgãos correicionais a tomada de providências aptas à sua resolução, não é ela, substancialmente, o propulsor da necessidade de deslocamento da competência. Ao contrário, é a ineficácia do Estado, revelada pela total ausência de capacidade de mover-se e, assim, de cumprir papel estruturante de sua própria existência organizacional, o fator desencadeante da federalização.

Ao longo destes mais de 15 anos foram apreciados 13 IDCs pelo STJ, até fevereiro de 2021, à análise de cada um deles, naquilo que é importante para este estudo, ressaltando, desde já, que todos os apontamentos foram retirados do STJ:

a) IDC 1: O IDC 1/DF trata da morte da missionária norte-americana Dorothy Stang em 12/2/2005, representante dos direitos humanos no que tange aos conflitos agrários no local, ocorrido no interior do Pará. O STJ entendeu ausentes os pressupostos legais e fáticos para o deslocamento. O tema central do IDC é a violência pela disputa de terras (agrária) no Brasil.

b) IDC 2: O IDC 2/DF cuida do caso do advogado e vereador pernambucano Manoel Bezerra de Mattos Neto assassinado em 24/01/2009, assim como denunciantes e testemunhas do caso, que apontavam a atuação de grupos de extermínio na fronteira com os Estados da Paraíba e Pernambuco (data do julgamento: 27/10/2010). O STJ entendeu presentes os pressupostos legais e fáticos para o deslocamento. O tema central do IDC é a violência de grupos de extermínio.

c) IDC 3: O IDC 3/GO trata da tortura e homicídios levados a efeito por autoridades policiais do Estado de Goiás. O STJ entendeu presentes os pressupostos legais e fáticos para o deslocamento de parte das ações penais em curso, julgando, assim, parcialmente procedente o pedido (data do julgamento: 10/12/14). O tema central do IDC é a violência policial e a morosidade do Poder Judiciário. 
d) IDC 4: O IDC 4/PE foi manejado por Sandro Ricardo da Cunha Moraes, Ministro do Tribunal de Contas de Pernambuco, em razão de que 0 ato do Tribunal de Contas local, que culminou com sua aposentadoria por invalidez permanente, violando "segredo de justiça" para as causas de sua aposentação, colocando sua família e ele em risco na sociedade que convivem. Foi negado seguimento ao IDC, haja vista a ilegitimidade do postulante, pessoa física não imbuída da qualidade de Procurador Geral da República. Julgado monocraticamente pelo Ministro Rogério Schietti Cruz no dia 20 de maio de 2014.

e) IDC 5: O IDC 5/PE trata da morte do Promotor de Justiça estadual Thiago Faria Soares, decorrente de provável ação de grupos de extermínio que atuam no interior do Estado de Pernambuco (região conhecida como "Triângulo da Pistolagem"). O STJ entendeu presentes os pressupostos legais e fáticos para o deslocamento (data da decisão: 14/11/2014). O tema central do IDC é a violência de grupos de extermínio.

f) IDC 9: IDC 9/SP trata da Chacina do Parque Bristol (Zona Sul de SP) ou "Maio Sangrento (ou crimes de maio)", que culminou na morte de mais de 500 pessoas em São Paulo em maio de 2006, ainda segue sem julgamento. O Instituto Conectas foi admitido como "amicus curiae".

g) IDC 10: O IDC 10/DF trata da Chacina do Cabula, operação policial conduzida em Salvador/BA que resultou na morte de 12 pessoas entre 15 e 28 anos e em 6 feridos, em fev./2015 (data do julgamento 28/11/2018). O STJ entendeu ausentes os pressupostos legais e fáticos para o deslocamento. O tema central do IDC é a violência policial e parcialidade das autoridades locais.

h) IDC 11: Neste IDC foi alegada a parcialidade do TJ do Estado de Ceará e do Juizado Especial de Violência Doméstica e Familiar. Foi reconhecida a ilegitimidade ativa, haja vista não ter sido ajuizado pelo PGR, o STJ não divulgou o nome restando consignado apenas (H. de P. F.) 
i) IDC 14: O IDC 14/DF trata da greve dos policiais militares do Estado do Espírito Santo, sob a alegação da falta de parcialidade das autoridades estaduais para conduzir a investigação e imputar responsabilidades. O STJ entendeu ausentes os pressupostos legais e fáticos para o deslocamento (data do julgamento: 08/08/18). O tema central do IDC é a violência policial e a imparcialidade das autoridades locais.

j) IDC 15: O IDC 15/CE cuida de mortes causadas por grupos de extermínio no Ceará, dos quais teriam participado autoridades públicas estaduais, ainda está pendente de julgamento. $O$ tema central é a atuação de grupos de extermínio e a violência estatal.

k) IDC 21: O IDC 21/RJ aduz sobre as chacinas ocorridas na Favela Nova Brasília no Estado do Rio de Janeiro, em episódios de mortes e violência estatal em operações policiais entre os anos de 1994 e 1995. O tema central é a violência estatal.

I) IDC 22: IDC 22/RO trata de homicídios e torturas de pessoas vinculadas a ligas de camponeses ocorridos em 2009, 2011, 2012 e 2016, refere-se a crimes graves com suspeita de agentes estatais de segurança pública em Rondônia, ainda está pendente de julgamento. Tema central morosidade da justiça e violência estatal.

m) IDC 24: O IDC 24/DF cuida do popular caso do assassinato de Marielle Franco, vereadora do Município do Rio de Janeiro, e Anderson Gomes, seu motorista, em 14 de março de 2018. O STJ entendeu ausentes os pressupostos legais e fáticos para o deslocamento (data do julgamento: 27/05/20). O tema central do IDC são as milícias atuantes no Rio de Janeiro.

Autuações equivocadas nos IDCs $6,7,8,12,13,16,17,18,19,20$ e 23 e processos em segredo de justiça impedem maior detalhamento neste ponto. De qualquer forma, depois de ampla pesquisa, ainda foi possível achar referência a um IDC, não numerado em razão do segredo de justiça, que tem por escopo apurar violações a direitos de adolescentes em unidade de socioeducação no Estado do Espírito Santo. 
Estas informações foram atualizadas até fevereiro de 2021.

Temas consagrados da temática humanista jamais estiveram presentes nos incidentes, como assuntos referentes às crianças e adolescentes, idosos, mulheres etc. Evidentemente, que estes foram vítimas dos fatos que ensejaram os incidentes, existindo uma preponderância para casos de homicídio. Aponta-se, ainda, que em diversos casos, a própria instauração do IDC, por si só, impulsionou as investigações, o que revela a incidência da morosidade e parcialidade das autoridades encarregadas da investigação e do próprio Poder Judiciário.

\section{CONSIDERAÇÕES FINAIS}

No início deste estudo, foi informado que seria realizada uma ampla análise do que se verificou com o IDC desde a sua inclusão no ordenamento pátrio, no aspecto processual e material e prático, bem como responder, por meio dos métodos apontados, o que poderia ser aperfeiçoado no instituto processual, para fins de ampliação dos seus efeitos humanitários. Diante de todo exposto, percebe-se a precariedade da dogmática do IDC no âmbito Constitucional, sendo urgente reforma legislativa (PEC ou Lei Federal) para alargar o rol de legitimados, para que a tutela dos Direitos Humanos no Brasil caminhe para maior salvaguarda.

A expressão "em qualquer fase do inquérito ou processo", presente do no dispositivo Constitucional, deve ser interpretada de forma teleológica, sistemática e evolutiva para que seja autorizado o incidente no âmbito de qualquer processo investigatório (inquérito civil, por exemplo), e não apenas no âmbito criminal, como se tem verificado na prática, conforme se teve a oportunidade de estudar ao longo de texto acadêmico, mas também no âmbito civil.

O escopo deste artigo é trazer reflexões técnicas, práticas e críticas sobre o IDC, o que se acredita tenha sido alcançado. Foi explorado detalhadamente os meandros processuais dos IDCs na jurisprudência do STJ, trazendo o que se tem decidido de mais recente sobre o tema. Todos os IDCs ajuizados foram explorados, estudados e 
analisados, havendo relevantes informações para os militantes de Direitos Humanos na área processual. Há vasto conteúdo de direito material (tratados internacionais) a ser explorados nos IDCs.

A jurisprudência admite a tutela antecipada, o amicus curiae, isentando o incidente de custas. O IDC tem como principais pressupostos: i) a existência de grave violação a direitos humanos; ii) o risco de responsabilização internacional decorrente do descumprimento de obrigações jurídicas assumidas em tratados internacionais; e iii) a incapacidade das instâncias e autoridades locais de oferecer respostas efetivas. $\mathrm{O}$ IDC pode ser manejado em qualquer momento da lide, seja na fase de investigação, civil ou criminal, seja no âmbito recursal, ou mesmo após o trânsito em julgado.

\section{REFERÊNCIAS}

BRASIL. Proposta de Emenda à Constituição $n^{\circ}$ 31, de 2017. Disponível em: <https://www25.senado.leg.br/web/atividade/materias/-/materia/130919>. Acesso em: $31 / 01 / 21$.

BRASIL. Constituição da República Federativa do Brasil de 1988. Disponível em: $<$ http://www.planalto.gov.br/ccivil_03/constituicao/constituicao.htm>. Acesso em: $20 / 01 / 21$.

FILHO, V. B. Federalização das violações de direitos humanos. Brasília a. $44 \mathrm{n}$. 175 jul./set. $2007 . \quad$ Disponível em: <https://www12.senado.leg.br/ril/edicoes/44/175/ril_v44_n175_p67.pdf>. Acesso em: 20/02/21.

MALATO, L. E. F. R. Federalização da competência nos crimes contra direitos humanos. Pontifícia Universidade Católica de São Paulo, São Paulo, 2007. Disponível em: <https://sapientia.pucsp.br/handle/handle/7530>. Acesso em: $20 / 12 / 21$. 
MAZZUOLI, V. de O. Curso de Direitos Humanos. $2^{a}$ edição. São Paulo: Editora Método, 2015.

PIOVESAN, F. Direitos Humanos e Direito Constitucional Internacional. 12 edição. São Paulo: Editora Saraiva, 2013.

RAMOS, A. de C. Teoria Geral dos Direitos Humanos na Ordem Internacional. 4a edição. Rio de Janeiro: Editora Renovar, 2014.

SUPERIOR TRIBUNAL DE JUSTIÇA. STJ. Jurisprudência do STJ. Disponível em: <https://scon.stj.jus.br/SCON/>. Acesso em: 05/02/21.

SUPREMO TRIBUNAL FEDERAL. STF. Ação Direta De Inconstitucionalidade 3493. 2015a.

Disponível

em:

<http://portal.stf.jus.br/processos/detalhe.asp?incidente=2294413>. Acesso em: 05/02/21.

SUPREMO TRIBUNAL FEDERAL. STF. Ação Direta De Inconstitucionalidade 3486. 2015b.

Disponível

em:

$<$ http://portal.stf.jus.br/processos/detalhe.asp?incidente=2293221>. Acesso em: $05 / 02 / 21$

\section{APÊNDICE- REFERÊNCIA NOTA DE RODAPÉ}

3. Art. 109. Aos juízes federais compete processar e julgar: $\S 5^{\circ}$ Nas hipóteses de grave violação de direitos humanos, o Procurador-Geral da República, com a finalidade de assegurar o cumprimento de obrigações decorrentes de tratados internacionais de direitos humanos dos quais o Brasil seja parte, poderá suscitar, perante o Superior Tribunal de Justiça, em qualquer fase do inquérito ou processo, incidente de deslocamento de competência para a Justiça Federal. (Incluído pela Emenda Constitucional n 45, de 2004) 
4. Art. 109. Aos juízes federais compete processar e julgar: V-A as causas relativas a Direitos Humanos a que se refere o $§ 5^{\circ}$ deste artigo;

5. Artigo 28. Cláusula federal: 1. Quando se tratar de um Estado Parte constituído como Estado federal, o governo nacional do aludido Estado Parte cumprirá todas as disposições da presente Convenção, relacionadas com as matérias sobre as quais exerce competência legislativa e judicial. 2.No tocante às disposições relativas às matérias que correspondem à competência das entidades componentes da federação, o governo nacional deve tomar imediatamente as medidas pertinente, em conformidade com sua constituição e suas leis, a fim de que as autoridades competentes das referidas entidades possam adotar as disposições cabíveis para o cumprimento desta Convenção.

6. Art. 103. Podem propor a ação direta de inconstitucionalidade e a ação declaratória de constitucionalidade: (Redação dada pela Emenda Constitucional № 45, de 2004) I - o Presidente da República; II - a Mesa do Senado Federal; III - a Mesa da Câmara dos Deputados; IV a Mesa de Assembleia Legislativa ou da Câmara Legislativa do Distrito Federal; (Redação dada pela Emenda Constitucional no 45, de 2004); V o Governador de Estado ou do Distrito Federal; (Redação dada pela Emenda Constitucional n4, de 2004); VI - o Procurador-Geral da República; VII - o Conselho Federal da Ordem dos Advogados do Brasil; VIII - partido político com representação no Congresso Nacional; IX - confederação sindical ou entidade de classe de âmbito nacional. E: Art. $2^{\circ}$ e Art. 12-A da Lei $\mathrm{n}^{\circ}$ 9.868/99 e Art. $2^{\circ}$, I, da Lei $\mathrm{n}^{0}$ 9.882/99.

7. Art. 134. A Defensoria Pública é instituição permanente, essencial à função jurisdicional do Estado, incumbindo-Ihe, como expressão e instrumento do regime democrático, fundamentalmente, a orientação jurídica, a promoção dos direitos humanos e a defesa, em todos os graus, judicial e extrajudicial, dos direitos individuais e coletivos, de forma integral e gratuita, aos necessitados, na forma do inciso LXXIV do Art. 5ำ desta Constituição Federal. (Redação dada pela Emenda Constitucional no 80 , de 2014) 
8. Ementa: Dá nova redação aos arts. 103 e 109, para dispor sobre a legitimidade do Defensor Público-Geral Federal para a ação direta de inconstitucionalidade, a ação declaratória de constitucionalidade e o incidente de deslocamento de competência para a Justiça Federal.

9. Art. 5 LIII - ninguém será processado nem sentenciado senão pela autoridade competente;

Enviado: Julho, 2021.

Aprovado: Agosto, 2021. 